\title{
International Research Focus: Nano 2004 Conference Held in India
}

The growing importance of nanocrystalline materials has drawn together scientists, engineers, and technologists worldwide in order to address, exchange, and communicate their ideas and experiences for realizing and exploiting the full potential of nanotechnology. The Kolkata Chapter of the Materials Research Society of India (MRS-I), led by chapter vice president N.R. Bandyopadhyay, joined the Institution of Engineers (India) in the organization of a three-day international conference on Nanomaterials: Synthesis, Characterization, and Application. S. Bandyopadhyay, of the Materials Science and Engineering Department in the University of New South Wales, chaired the international committee, and Sudipta Seal, of the Advanced Materials Processing and Analysis Center at the University of Central Florida, served as an advisor on the International Committee. The conference was held in Kolkata November 4-6, 2004.

The conference focused on the fundamental aspects, technological developments, and potential applications of nanoscience in the context of India's needs and involvement in the current technological revolution. The conference offered lectures and poster presentations broadly covering nanoscience themes. Distinguished scientists, engineers, and technologists as well as young researchers from around the world participated, creating a platform for scientists and students from East and West. Proceedings of the conference papers were published by Tata McGraw-Hill. The proceedings include 30 reviewed manuscripts from keynote and invited talks plus 42 reviewed contributory papers.

India's president and foremost technologist, A.P.J. Abdul Kalam, in his message to the conference attendees, said, "The conference can be used as an occasion by the participating experts in the area of nanomaterials to exchange their views and ideas on how to move ahead in this

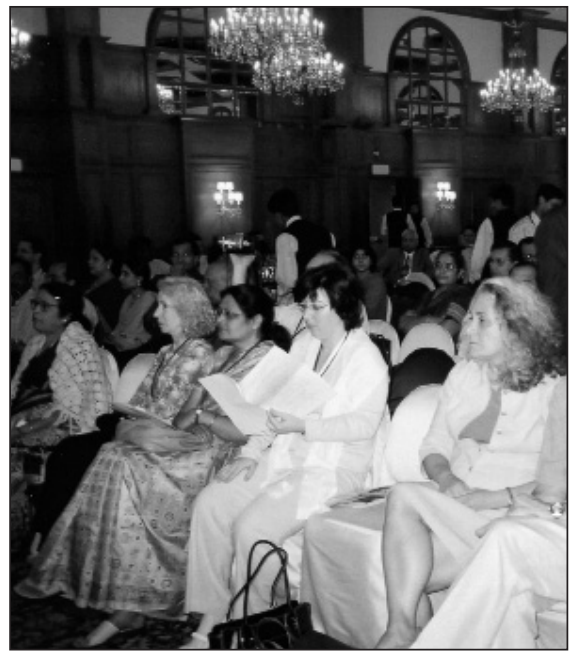

Attendees at the international conference on Nanomaterials: Synthesis,

Characterization, and Application, held in Kolkata, India, November 4-6, 2004.

important frontier technology.... It will also be in the future the central focus of many technologies to converge and open a large number of applications...."

The conference created a holistic approach to understanding and developing the potential of this emerging field. On behalf of the conference, N.R. Bandyopadhyay expressed appreciation for the Indian government's effort to "prepare a policy document on the steps the country could take to be in the forefront of developments in the field of nanotechnology."

Bandyopadhyay recommended a more speedy and concerted effort on behalf of the government to develop and implement a clear roadmap for pursuing research and development (R\&D) priorities. This is to ensure that even if India missed the revolution in microelectronic materials, the country should be at the cutting edge of progress in nanomaterials. The government organizations sponsoring and leading scientific research in the country, such as the Department of Science and Technology, the Council of Scientific and Industrial Research, and the All India Council of Technical Education, will soon formulate an immediate plan to allocate funds to the different universities, $R \& D$ laboratories, and related organizations for promoting directed research in the field, said Bandyopadhyay. He said that the current need in India is to put more emphasis on those aspects of research in nanomaterials that could have a positive impact on the society and are likely to touch the common person. The central focus should be the development of a large number of applications. He said it is crucial to identify and characterize the industries that could benefit most from the use of engineered nanomaterials and sensitize those industries about the issue. This should facilitate industry-academic collaboration, which is imperative for further advancement and for overcoming the present lukewarm response of the industry in funding R\&D.

All research on nanomaterials should systematically consider the environmental and ethical consequences of the technology, and to limit these consequences to intended effects, said Bandyopadhyay. Significant research is required on environmental models and risk management as well as on the theory, mechanisms, and experimental designs for built-in safeguard systems. In this connection, a proposal is being made to create an international committee, consisting of experts in the relevant fields, to draft a legislative code to monitor R\&D in nanomaterials. Bandyopadhyay also said that the possibility of introducing a postgraduate course on nanoscience and nanotechnology should be explored.

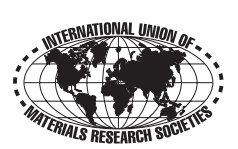

\begin{tabular}{|c|c|c|c|c|}
\hline \multicolumn{5}{|c|}{ MRS Future Meetings } \\
\hline \multirow{2}{*}{$\begin{array}{l}2005 \text { FALL MEETING } \\
\text { Nov. 28-Dec. } 2 \\
\text { Exhibit: Nov. 29-Dec. } 1 \\
\text { Boston, MA }\end{array}$} & \multicolumn{4}{|l|}{ Meeting Chairs: } \\
\hline & $\begin{array}{l}\text { Yang-Tse Cheng } \\
\text { General Motors R\&D Ctr. } \\
\text { yang.t.cheng@gm.com }\end{array}$ & $\begin{array}{l}\text { David S. Ginley } \\
\text { National Renewable } \\
\text { Energy Laboratory } \\
\text { david_ginley@nrel.gov }\end{array}$ & $\begin{array}{l}\text { Kathryn E. Uhrich } \\
\text { Rutgers University } \\
\text { uhrich@rutchem.rutgers.edu }\end{array}$ & $\begin{array}{l}\text { Ralf B. Wehrspohn } \\
\text { Paderborn University } \\
\text { wehrspohn@physik. } \\
\text { uni-paderborn.de }\end{array}$ \\
\hline 2006 SPRING MEETING & Meeting Chairs: & & & \\
\hline $\begin{array}{l}\text { April 17-21 } \\
\text { Exhibit: April 18-20 } \\
\text { San Francisco, CA }\end{array}$ & $\begin{array}{l}\text { Gregg S. Higashi } \\
\text { Applied Materials } \\
\text { gregg_s_higashi@amat.com }\end{array}$ & $\begin{array}{l}\text { Viola Vogel } \\
\text { Swiss Federal Institute } \\
\text { of Technology, ETH } \\
\text { viola.vogel@mat.eth.eh }\end{array}$ & $\begin{array}{l}\text { Paul S. Drzaic } \\
\text { Alien Technology } \\
\text { Corporation } \\
\text { pdrzaic@alientechnology.com }\end{array}$ & $\begin{array}{l}\text { J. Charles Barbour } \\
\text { Sandia National Laboratories } \\
\text { jcbarbo@sandia.gov }\end{array}$ \\
\hline
\end{tabular}




\section{Sino-European Bilateral Meeting on Materials and Energy Held in December 2004}

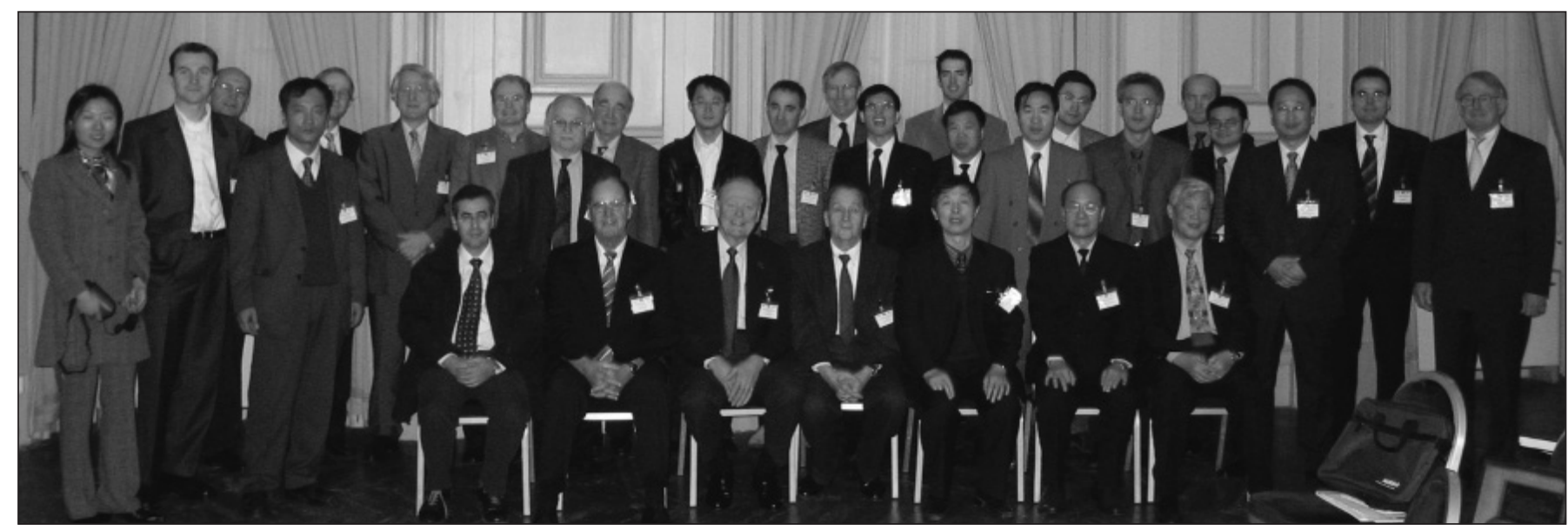

Delegates from China and Europe convened in Nice, France, for a bilateral conference on "Materials Aspects for Future Energy Supply."

High-ranking scientific delegations from China and Europe, invited by the Chinese and European Materials Research Societies (C-MRS and E-MRS), convened at the 2nd Biannual Sino-European Bilateral Meeting December 6-8, 2004, in Nice, France. The theme, "Materials Aspects for Future Energy Supply," was timely in terms of the acute situation regarding the increasing world population, the growing energy demand, and the consequences for the global environment.

Scientists from the Academy of Technology in Beijing as well as from other larger institutions in China met European colleagues representing a large number of countries and institutions, working in the most advanced domains of materials science for energy, from nuclear to fuel cells and photovoltaics to biomass. The meeting, attended by about 40 scientists, was opened by the delegate from the Chinese Embassy in Paris, followed by the presidents of both organizing societies.

About 25 talks were presented alternately by scientists from China and Europe. Technical reports included the recent status and future of energy sources in China in comparison to the situation in Europe. The topics included the use of hydrogen as an energy vector; carbon capture, storage, and sequestration; fuel cells; biomass with energetic conversion of bioresources (e.g., heat and power generation); photovoltaics; geothermal, solar, wind, nuclear, and fission systems; and substantial improvement of energy efficiency, building construction, and industry.

The materials challenges for lowtemperature polymer exchange membranes (PEM) fuel cell and high-temperature solid-oxide fuel cells (SOFCs), as well as the storage of their energy carriers, were heavily discussed in the session on hydrogen and fuel cells. There are already some applications in market niches, but generally all of these fuel cell technologies are still suffering enormous cost pressures if applied in a commercially competitive market. In the session on materials for photovoltaics, the different types of photovoltaic systems and their challenges with respect to efficiency, visions, and-most important-costs were presented.

In the session on the status and vision of energy in China and Europe, it became very clear that the perspectives and actions to be taken in a developing country such as China have to be considered differently from the situation in the comparable industrialized countries of Europe. In a separate session, the socio-economic aspects were also discussed, with various models presented either by national or international authorities. In this session, on other materials for energy supply, it was clear to all the experts that the reduction of $\mathrm{CO}_{2}$ emissions is a priority. Even though renewable decentralized energy technologies such as solar energy may play an important role in the future, there remains a more urgent need, where centralized energy technologies such as fossil (limited resources) and nuclear (fission and fusion) will play a major role for the coming 50 years. Representatives of the European Commission presented their views on both specific programs and the materials policy in general for energy-related demands. The participants concluded that technology breakthroughs in all of these energy areas are highly dependent on innovations and the outcome of new materials.

Directly after the conference, the delegates visited the French Nuclear Research Center of the CEA in Cadarache, where they were introduced to the latest activities in fusion research, especially with respect to materials development. Attendees also had the opportunity to see the Tokamac Tore Supra, which is equipped with a system of superconducting magnets that generates a permanent toroidal magnetic field and enables the study of plasma in a quasi-permanent regime. The tokamak is the forerunner of the fusion reactor ITER. Details of this project were presented and discussed. This visit was of particular interest to the delegation from China, since China will become one of the founding members of this project, planned to be in operation around 2010.

The next bilateral conference is being organized for 2006 in China.

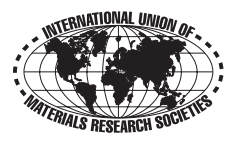

